\title{
Editorial
}

\section{Circulating Insulin-binding Antibodies}

\author{
A. B. Kurtz and J. D. N. Nabarro \\ Middlesex Hospital, London, England
}

Insulin was first used in the treatment of diabetic patients in 1921 and the first immunological problem associated with its use was reported in 1922 [1]; a patient developed anaphylaxis after the injection of a porcine, but not of a bovine insulin preparation. At that time insulin preparations were very impure and the antigen was probably a contaminating substance rather than insulin. In subsequent years a small number of patients were found to have developed insulin resistance after treatment with insulin [2]. In 1944 Lowell [3] reported the occurrence of circulating insulin-neutralizing antibodies and insulin resistance in a patient who also had allergic symptoms; the serum of this patient neutralized beef/pork, but not human insulin when tested in mice. Using radioactive iodine-labelled insulin Berson, Yalow and co-workers [4] found insulin-binding antibodies in the serum of all insulin-treated patients. In further studies they characterized these antibodies as non-precipitating insulin-binding antibodies from which the insulin is freely dissociable and the antibodies heterogeneous as regards affinity for insulin $[5,6]$. They noted that different sera showed marked variations in affinity for insulins from different animal species [7]. Their predictions were [4]; first, that antibodies might, if present in high titre, cause resistance to insulin; secondly, that the release of antibody bound insulin at inopportune times might cause hypoglycaemia; and, thirdly that circulating insulin-antibody complexes might cause vascular damage and contribute to the complications seen in long standing diabetics. Resistance caused by insulin binding antibodies has never been common [8] in spite of the fact that virtually all patients treated with insulin develop antibodies. Hypoglycaemia, caused by the release of antibody bound insulin, was described in an insulin-treated patient who had a very high titre of insulin-binding antibody and who suffered repeated hypoglycaemic episodes, sometimes days after receiving insulin [9]. A rare syndrome in which hypoglycaemic episodes occur in subjects who have high titres of insulin binding-antibody yet who have never been treated with insulin has been reported $[10,11]$. The third prediction of Berson and Yalow, that insulin-antibody complexes might contribute to the vascular complications of diabetics, has not for the most part, been confirmed in studies of retinopathy, basement membrane thickening and 'general complications' [12-14].

The syndromes, caused by insulin-binding antibodies, of resistance to insulin and of hypoglycaemia are both rare and in the vast majority of patients insulin-binding antibodies appear to have little or no clinical effects. It has been suggested [15] that these antibodies could act as a buffer, storing insulin which, when released, would act to produce more stable control of the blood glucose. No real evidence has supported this suggestion; continuing pancreatic Bcell function, as evidenced by C-peptide secretion, appears to be a much more important determinant of stable control [16-18]. Insulin-binding antibodies do however have a considerable effect on the pharmacokinetics of insulin. This was shown by Bolinger et al. [19] who correlated the half-life of disappearance from the circulation of 131-iodinated insulin with different treatment regimes. For those patients with a long half-life for insulin short acting insulin tended to be sufficient, given twice or even only once a day, while those patients with a short half-life for insulin tended to require insulin preparations with prolonged action. In subjects with very slow clearance of insulin from the circulation hypoglycaemic episodes were delayed and occurred many hours after soluble insulin administration. For most patients the titre of insulin binding antibody does not correlate well with the insulin dose [20]. There are so 
many factors interacting in their effects on diabetic control that identification of the small effect antibodies may have on insulin dose is difficult in patient groups. However, in the individual antibodies may affect the insulin dose differentially if there is a marked difference of antibody affinity for pork and beef insulins. The usual clinical problem is that of a patient on a high dose of beef insulin for whom a change to pork insulin is contemplated. A lower dose of pork insulin is required if the patient's antibodies have higher affinity for beef than for pork insulin and in vitro tests are a good guide to this [21,22].

Over the last 10 years highly purified insulins have been available and attention has been focussed on their reduced antigenicity $[23,24]$. In spite of the fact that insulin-binding antibodies, for the most part, have no deleterious clinical effects, the use of insulin preparations of low antigenicity would seem desirable [25]. The currently available highly purified insulins differ from conventional insulin preparations in several respects. The high molecular weight $a$ and $\mathrm{b}$ components have been removed; the a component consists of heterogeneous material with insulin immunoreactivity and the $b$ component consists of proinsulin, intermediate insulins and non-dissociable insulin dimers $[26,27]$. Both the $a$ and $b$ components are antigenic. Other hormones such as glucagon, pancreatic polypeptide, somatostatin and vasoactive intestinal peptide have also been removed. The removal of the proinsulin and contaminating hormones has been sufficiently complete to ensure that antibodies to these components are not detectable in patients treated only with purified insulin [28]. Purification also removes chemically altered insulins such as desamido and arginine insulins and insulin ethylester.

Insulin, prepared from a particular species, can be antigenic even in that species $[29,30]$; this has been demonstrated in man although only with an impure preparation of insulin [31]. This finding led to the suggestion that chemical alteration of the insulin during its preparation had rendered it antigenic [31, 32]. Insulin is stored naturally as crystals of hexameric insulin in the islet B-cells and then released directly into the portal circulation where it rapidly dissociates into dimers and then monomers $[33,34]$. Pure beef, pork or human insulins will form dimers at concentrations over $10^{-7} \mathrm{~mol} / \mathrm{l}$ and, in the presence of zinc, will form hexamers [34]. This process should be totally reversible. A completely pure insulin should therefore be absorbed from an injection site into the circulation, where the insulin concentration is of the order of $10^{-10} \mathrm{~mol} / 1$, as monomeric insulin and there should be no residue of insoluble or polymerized material. However the formation of a non- dissociable polymer occurs in both conventional beef and highly purified pork insulins. We find, using gel chromatography, that there are small amounts of non-dissociable higher molecular weight material, with insulin immunoreactivity, in highly purified insulin preparations: the amount of this material increases with storage, more rapidly at $30^{\circ} \mathrm{C}$ than at $4^{\circ} \mathrm{C}$. Rather more of this material can be found in conventional acid beef insulin than in the highly purified pork preparations. It is likely that the amount of this material is underestimated as it is readily lost on chromatography columns because of its lipophilic nature. Beef insulin is less soluble in water, and more lipophilic than pork insulin because of amino acid differences in the A chain, in particular the substitution at $\mathrm{A} 8$ of an alanine for the threonine which is in pork insulin [35]. A chemically altered insulin, such as arginine insulin, is even more lipophilic. The more lipophilic an insulin the greater will be its tendency to non-dissociable polymerization.

Therapeutically administered insulin is given either as a solution, or as a suspension of insulin crystals or as a suspension of crystals of complexed insulin (such as the protamine insulin crystals in isophane or protamine zinc insulins). After injection the insulin remains for an appreciable time in the tissues at $37^{\circ} \mathrm{C}$, with a very high local concentration of insulin and also, for many preparations, of zinc. Even if the initial injection were free of non-dissociable polymerized insulin the conditions during absorption are conducive to polymerization. This applies in particular to longer acting insulins. It is not surprising that protamine zinc insulin appears to be a particularly antigenic insulin preparation. Insulin aggregation is also a problem in the solutions used with infusion devices and the aggregates may block cannulae [36]. There is no direct evidence that these polymers are antigenic but current immunological theory about the initiation and maintenance of antibody production would predict that they should be [37].

A poorly soluble polymer is likely to be engulfed by macrophages, which is a potent stimulus to antigenicity. In addition a polymer will have more immunological determinants than a monomer and this will allow association both with T-lymphocytes and with B-lymphocytes; this interaction of T- and $\mathrm{B}$-cells is required both for initiation and maintenance of antibody secretion. Insulin monomer may well behave as a hapten, in which case it would be unable to interact with T-cells, but would be able to bind to circulating antibody and also to react with the antibody on the surface of B-cells. This hapten-like behaviour would be insufficient to stimulate antibody 
production. The observation that insulin antibody titres decline in patients treated with highly purified insulin fits with this hypothesis [28, 38, 39].

Keck [40] has shown that in some strains of mice monomeric pork insulin has insufficient carrier determinants to be antigenic. When beef insulin was added to the pork insulin as a coimmunogen the pork insulin became antigenic, as judged by the development of antibodies to a conjugated derivative on the pork insulin. The interpretation of these experiments is that insulins from different species may have differing numbers of carrier determinants and that if extra carrier determinants are added antigenicity may be induced. Polymerized insulin clearly possesses multiple carrier determinants. One could anticipate that in some patients beef/pork insulin mixtures, even if highly purified, might be more antigenic than either unmixed beef or pork insulin. In addition Keck's study suggests that tolerance may be induced by an insulin mixture.

The antigenicity of insulin is, in mice, under the control of immune response genes [40]. In man HLA antigen typing has shown that higher insulin-binding antibody titres tend to occur in B15, with lower titres in B8 and DRw3 subjects [12, 41]. It is possible that this association is indirect. A factor such as continuing endogenous insulin secretion could influence antibody production firstly by an effect on the type and dose of insulin chosen for the patient, and secondly by an effect of the endogenous insulin itself on $\mathrm{T} / \mathrm{B}$ lymphocyte interaction.

The circulating insulin antibodies induced by insulin therapy appear to act only as a binding protein so that there is, in the circulation of these patients, both free insulin and antibody bound insulin: the free insulin concentration in the serum usually approximates to normal physiological insulin concentrations $\left(5-80 \mathrm{mU} / \mathrm{l} ; 0.3-6 \times 10^{-10} \mathrm{~mol} / \mathrm{l}\right)$ [42] while the total insulin concentration varies widely from patient to patient, depending on antibody titre, sometimes reaching concentrations of 5-10 U/l, (3-6 × 10 $\left.0^{-8} \mathrm{~mol} / \mathrm{l}\right)$, occasionally more [9]. In all cases the fraction of antibody binding sites occupied is low as would be anticipated from the law of mass action. The free insulin concentration is of the order $10^{-10} \mathrm{~mol} / \mathrm{l}$ while the average equilibrium constant for these antibodies is usually much less than $10^{10} \mathrm{l} / \mathrm{mol}[5,17,43]$; at $50 \%$ occupancy of binding sites the equilibrium constant equals the reciprocal of the free hormone concentration. The clinical situation is one, therefore, of antibody excess with a soluble dissociable monovalent antibody-insulin complex. This type of complex is not cleared by the reticulo-endothelial system and does not fix complement. Other types of insulin-antibody complex have been demonstrated in guinea pigs and in patients with very high antibody titres $[44,45]$; with these large complexes clearance by the reticuloendothelial system would be expected together with an increased requirement for insulin (i. e., resistance). Steroids block the clearance of complexes and are effective in the treatment of insulin resistance of this type [8]. In most patients antibody titres are fairly stable over long periods of time. This is to be expected if the antigenicity of the insulin preparation remains constant and the free insulin concentration, which is also a factor influencing antibody production, is reasonably constant. Fluctuations of antibody secretion occur with marked changes of insulin dose and with changes of the insulin preparation to one with different carrier determinants. There is decreased antibody secretion in most patients when they change from a conventional beef to a highly purified pork insulin and on resumption of the former insulin antibody secretion increases and the antibody titre increases to the initial level [28].

Insulin binding antibodies are heterogenous; although there is in fact a spectrum of antibodies most reports separate them into two groups and there is usually a lesser concentration of higher affinity antibodies with a greater concentration of lower affinity antibodies $[5,17,43]$. Different dissociation rate constants for the 'two' antibody fractions account for the different affinities.

The distribution of antibody bound insulin between the slowly and rapidly dissociating antibodies is complex and depends on the time the insulin has been bound in the circulation. With increasing time an increasing fraction of the insulin becomes bound to slowly dissociating antibodies and therefore becomes less available to tissues [5]. Not only does this heterogeneity make pharmacokinetic studies of the effect of insulin antibodies on insulin therapy difficult but it also makes quantitation of the amount of insulin antibody in serum difficult.

With high titres of antibody characterization of the two main types of binding site by Scatchard analysis is possible, but with the lower titres now more usually seen in patients treated with purer insulins Scatchard analysis is both more difficult and less precise. A simple estimation of 125-iodinated insulin binding under standard conditions gives sufficient information for clinical and comparative purposes $[28,46,47]$. Opinions vary as to whether endogenous insulin should be removed before antibody estimation or not. The usual method of removing insulin is to acidify serum and then treat it with charcoal. Our view is that removal of insulin does not materially affect the interpretation of the results; insulin removal may well be incomplete if the $\mathrm{pH}$ is not low 
enough and antibody may be denatured if the $\mathrm{pH}$ is too low. Because of this problem of quantifying heterogeneous antibody a large number of different methods have been described; the classical approach of immunologists, using a 'titre' [37], has not so far as we are aware, been used for insulin antibodies.

In some patients insulin binding antibodies can have quite marked differences in affinity for insulins of different species of origin. This is accounted for by different association rate constants for the different insulins [48]. The greatest affinity is usually for beef insulin [27]. Resistance to beef insulin may be associated with complete sensitivity to pork insulin [49]. This clinical situation can be easily predicted by in vitro tests $[21,22]$. Where there is resistance to pork insulin there may be greater sensitivity to desalanated pork insulin [50]. Desalanated pork insulin has lost the alanine at position B30 which is the only aminoacid difference between pork and human insulin. Fish insulins are structurally unlike beef and pork insulins and it has been suggested that they might be useful in some resistant patients [51]; they have activity in man and were used during World War II in Japan. In patients treated with beef or pork insulin antibody affinity to human insulin is variable but usually less than to beef or pork insulin. In subjects never treated with insulin, who have insulin-binding antibodies the affinity of the antibodies for human insulin tends to be the same as the affinity for pork insulin and to be greater than the affinity for beef insulin [10]. In order to distinguish antibodies formed as a response to insulin injection from those formed in the autoimmune syndrome reliance cannot be placed on affinity studies [11]; however antibodies to proinsulin or hormonal contaminants of insulin preparations, of which pancreatic polypeptide is the most antigenic, would only occur following insulin injection and their presence would exclude a diagnosis of the autoimmune insulin-antibody syndrome. Immunological identification of this syndrome will become more difficult as highly purified insulins are more widely used.

Insulin-binding antibodies of the IgG class could potentially have a number of effects; in practice virtually all insulin-dependent diabetics have these antibodies to a greater or lesser extent, with, so far as one can tell, no discernable effects in the majority. With increasing use of purified insulin preparations, with reduced antigenicity, antibody titres in the insulindependent diabetic population will fall and problems caused by insulin-binding antibodies will become even less frequent than they are today. In the future insulin resistance, of the type caused by antibodies, may only be seen as a secondary immune response; this is the only type of resistance we have seen over recent years (three cases). It occured in subjects who were given a short course of insulin, of a highly antigenic variety, and then, after many years without insulin, when treatment with insulin was resumed insulin resistance developed with high antibody titres. Resistance can occur even if the second immunization is with a highly purified insulin as was the case in two of our three subjects.

A further aspect of falling insulin-binding antibody titres in the insulin dependent diabetic population might be to alter the fractions of rapidly acting and intermediate insulins that are in general prescribed. Insulin-binding antibodies prolong insulin action [19] so that one would expect a higher proportion of rapidly acting insulin to be used in a population with high antibody titres, with a higher proportion of intermediate acting insulins being used in a population with low antibody titres. In the United Kingdom a high proportion of insulin prescribed is rapidly acting $(40 \%)$ and antibody titres are in general high because of the widespread use of conventional beef insulin preparations. In Scandinavia, where antibody titres are low and purified pork insulin use widespread, a considerably lower proportion of rapidly acting insulin is used (15\%). There are of course many other factors than antibody titre that could contribute to these prescribing differences. It is interesting to reflect that long acting insulin preparations were first developed in the 1930 s because increasing purification of regular insulin had shortened its time course of action [52].

Insulin antibodies cross the placenta and can be detected in cord blood [53]. Although a role in neonatal hypoglycaemia might be expected evidence against this has been presented for infants of insulindependent diabetic mothers [54]. However, in one reported case the mother had autoimmune insulin antibodies and the infant had a high titre of insulinbinding antibody and experienced episodes of severe hypoglycaemia which were attributed to release of antibody-bound insulin [55]. Although experiments in rabbits have shown that antibodies, produced in response to an impure insulin, caused an insulitis, and occasionally even diabetes, there is no evidence that this occurs in the human foetus if it is exposed to insulin antibodies and in addition antibodies produced by immunization with highly purified insulin did not produce an insulitis in the rabbit [56]. Antibodies to other hormones occur in insulin treated diabetics and it is conceivable that they could have metabolic effects. Antihormone antibodies seem for the most part to have very little clinical effect although a recent report suggests that glucagon binding antibodies in insulin-dependent diabetic children are 
associated with a tendancy to develop hypoglycaemia [57].

For the future we must expect that nearly all insulin treated patients will have clinically insignificant insulin-binding antibodies; this will almost certainly be the case even if 'human' insulin, manufactured by gene-splicing techniques, becomes available for clinical use as its antigenicity will probably be similar to pork insulin.

\section{References}

1. Williams JR (1922) A clinical study of the effects of insulin in severe diabetes. J Metab Res 2: 729-751

2. Joslin EP (1935) The treatment of diabetes mellitus, 5th ed. Henry Kimpton, London, p 294-297

3. Lowell FC (1944) Immunologic studies in Insulin resistance: II the presence of a neutralizing factor in the blood exhibiting some characteristics of an antibody. J Clin Invest 23: 233-240

4. Berson SA, Yalow RS, Bauman A, Rothschild MA, Newerly $\mathrm{K}$ (1956) Insulin $1^{131}$ metabolism in human subjects. Demonstration of insulin binding globulin in circulation of insulin treated subjects. J Clin Invest 35: 170-190

5. Berson SA, Yalow RS (1959) Quantitative aspects of the reaction between insulin and insulin-binding antibody. J Clin Invest 38: 1996-2016

6. Berson SA, Yalow RS (1957) Studies with insulin-binding antibody. Diabetes 6: 402-405

7. Berson SA, Yalow RS (1959) Species-specificity of human anti-beef, pork insulin serum. J Clin Invest 38: 2017-2025

8. Oakley WG, Jones VE, Cunliffe AC (1967) Insulin resistance. Br Med J II: 134-138

9. Harwood R (1960) Insulin-binding antibodies and "spontaneous" hypoglycaemia. N Engl J Med 262: 978-979

10. Hirata Y, Tominaga M, Ito JI, Noguchi A (1974) Spontaneous hypoglycaemia with insulin autoimmunity in Graves' disease. Ann Intern Med 81: 214-218

11. Goldman J, Baldwin D, Rubenstein AH, Klink DD, Blackard WG, Fisher LK, Roe TF, Schnure JJ (1979) Characterization of circulating insulin and proinsulin-binding antibodies in autoimmune hypoglycaemia. J Clin Invest 63: 1050-1059

12. Schernthaner G, Ludwig H, Mayr WR (1979) Immunoglobulin G-insulin antibodies and immune region-associated alloantigens in insulin-dependent diabetes mellitus. J Clin Endocrinol Metab 48: 403-407

13. Deckert T, Egeberg J, Frimodt-Moller C, Sander E, Svejgaard A (1979) Basement membrane thickness, insulin antibodies and HLA-antigens in longstanding insulin dependent diabetes with and without severe retinopathy. Diabetologia 17: 91-96

14. Andersen $O O$ (1976) Clinical significance of anti-insulin antibodies. Acta Endocrinol (Kbh) 83 [Suppl 205]: 231-240

15. Dixon K, Exon PD, Malins JM (1975) Insulin antibodies and the control of diabetes. J Q Med 44: 543-553

16. Asplin CM, Hartog M, Goldie DJ (1978) Change of insulin dosage, circulating free and bound insulin and insulin antibodies on transferring diabetes from conventional to highly purified porcine insulin. Diabetologia 14: 99-105

17. Gonen B, Goldman J, Baldwin D, Goldberg RB, Ryan WG, Blix PM, Schanzlin D, Fritz KJ, Rubenstein AH (1979) Metabolic control in diabetic patients. Effect of insulin-secretory reserve (measured by plasma C-peptide levels) and circulating insulin antibodies. Diabetes 28: 749-753
18. Yue DK, Baxter RC, Turtle JR (1978) C-peptide secretion and insulin antibodies as determinants of stability in diabetes mellitus. Metabolism 27: 35-44

19. Bollinger RE, Morris JH, McKnight FG, Diederich DA (1964) Disappearance of ${ }^{131} I$ labeled insulin from plasma as a guide to management of diabetes. N Engl J Med 270: 767-770

20. Asplin CM, Hartog M, Goldie DJ, Alberti KGMM, Smythe P, Binder C, Faber O (1978) A comparison between diabetics receiving a high or low daily insulin dosage. Horm Metab Res 10: 365-369

21. Berson SA, Yalow RS (1966) Insulin in blood and insulin antibodies. Am J Med 40: 676-690

22. Devlin JG, Brien T, Stephenson N (1967) Relation between antibody and insulin dose. Br Med J I: 542-544

23. Schlichtkrull J, Brange J, Christiansen AH, Hallund $\mathrm{O}$, Heding LG, Jorgensen KH (1972) Clinical aspects of insulin-antigenicity. Diabetes 21 [Suppl 2]: 649-656

24. Yue DK, Turtle JR (1975) Antigenicity of "monocomponent" pork insulin in diabetic subjects. Diabetes 24: 625-632

25. Alberti KGMM, Nattrass M (1978) Highly purified insulins. Diabetologia 15: 77-80

26. Steiner DF, Hallund O, Rubenstein AH, Cho S, Bayliss C (1968) Isolation and properties of proinsulin, intermediate forms and other minor components from crystalline bovine insulin. Diabetes 17: 725-736

27. Chance RE, Root MA, Galloway JA (1976) The immunogenicity of insulin preparations. Acta Endocrinol (Kbh) 83 [Suppl 205]: 185-198

28. Kurtz AB, Matthews JA, Mustaffa BE, Daggett PR, Nabarro JDN (1980) Decrease of antibodies to insulin, proinsulin and contaminating hormones after changing treatment from conventional beef to purified pork insulin. Diabetologia 18: $147-150$

29. Lockwood DH, Prout TE (1965) Antigenicity of heterologous and homologous insulin. Metabolism 14: 530-538

30. Deckert T, Grundahl E (1970) The antigenicity of pig insulin. Diabetologia 6: $15-20$

31. Deckert T, Andersen OO, Grundahl E, Kerp L (1972) Isoimmunization of man by recrystallized human insulin. Diabetologia 8: 358-361

32. Berson SA, Yalow RS (1963) Antigens in insulin. Science 139: 844-845

33. Blundell TL, Cutfield JF, Cutfield SM, Dodson EJ, Dodson GG, Hodgkin DC, Mercola DA, Vijayan M (1971) Atomic positions in rhombohedral 2-Zinc insulin crystals. Nature 231: 506-511

34. Goldman J, Carpenter FH (1974) Zinc binding circular dichroism and equilibrium Sedimentation Studies on Insulin (bovine) and several of its derivatives. Biochemistry 13: $4566-4574$

35. Sanger F (1960) Chemistry of insulin. Br Med Bull 16: $183-200$

36. Albisser AM, Lougheed W, Perlman K, Bahoric A (1980) Nonaggregating insulin solutions for longterm glucose control in experimental and human diabetes. Diabetes 28: 241-243

37. Roitt I (1977) Essential immunology, third ed. Blackwell Scientific Publications, Oxford

38. Bruni B, D'Alberto M, Osenda M, Ricci C, Turco GL (1973) Clinical trial with monocomponent lente insulins. Preliminary report. Diabetologia 9: 492-498

39. Andreani D, Iavicoli M, Tamburrano G, Menzinger G, Maltarello C (1974) Comparative trials with monocomponent (MC) and monospecies (MS) pork insulins in the treatment of diabetes mellitus. Influence on antibody levels, on insulin requirement and some complications. Horm Metab Res 6: 447-454

40. Keck K (1977) Ir gene control of carrier recognition: III 
Cooperative recognition of two or more carrier determinants on insulins of different species. Eur J Immunol 7: 811-816

41. Bertrams J, Jansen FK, Grïneklee D, Reiss HE, Drost H, Beyer J, Gries FA, Kuwert E (1976) HLA-antigens and immunoresponsiveness to insulin in insulin-dependent diabetes mellitus. Tissue Antigens 8: 13-17

42. Nabarro JDN, Mustaffa BE, Morris DV, Walport MJ, Kurtz AB (1979) Insulin deficient diabetes. Diabetologia 16: 5-12

43. Baxter RC, Yue DK, Turtle JR (1976) Equilibrium binding studies of insulin antibodies in diabetic subjects. Clin Chem 22: $1089-1094$

44. Folling I (1976) Insulin - anti-insulin complexes. Acta Endocrinol (Kbh) 83 [Suppl 205]: 199-209

45. Irvine WJ, Al-Khateeb SF, DiMario U, Feek CM, Gray RS, Edmond B, Duncan LJP (1977) Soluble immune complexes in the sera of newly diagnosed insulin-dependent diabeties and in treated diabetics. Clin Exp Immunol 30: 16-21

46. Christiansen AH (1970) A new method for determination of insulin-binding immuno-globulins in insulin-treated diabetic patients. Horm Metab Res 2: 187-188

47. Gerbitz KD, Kemmler W (1978) Method for rapid quantitation and characterization of insulin antibodies. Clin Chem 24 : $890-894$

48. Kurtz AB, Matthews JA, Nabarro JDN (1978) Insulin-binding antibody: reaction differences with bovine and porcine insulins. Diabetologia 15: 19-22

49. Kurtz AB, Harrington MG, Matthews JA, Nabarro JDN (1979) Factitious diabetes and antibody mediated resistance to beef insulin. Diabetologia 16: 65-67

50. Kumar D (1979) Immunoreactivity of insulin antibodies in insulin-treated diabetics: significance of the beta-chain carboxy-terminal amino acid (B-30) of insulin. Diabetes 28: 994-100

51. Yalow RS, Berson SA (1964) Reactions of fish insulins with human insulin antiserum. N Engl J Med 270: 1171-1178

52. Poulsen JE (1967) Insulin; desirable and undesirable effects. Acta Med Scand [Suppl] 476: 91-100

53. Spellacy WN, Goetz FC (1963) Insulin antibodies in pregnancy. Lancet II: 222-224

54. Martin FI, Dahlenburg GW, Russell J, Jeffery P (1975) Neonatal hypoglycaemia in infants of insulin-dependent diabetic mothers. Arch Dis Child 50: 472-476

55. Nakagawa S, Suda N, Kudo M, Kawasaki M (1973) A new type of hypoglycaemia in a newborn infant. Diabetologia 9 : 367-375

56. Kloppel G (1976) 'Insulin' induced insulitis. Acta Endocrinol (Kbh) 83 (Suppl 205): 107

57. Villalpando S, Drash A (1979) Circulating glucagon antibodies in children who have insulin-dependent diabetes mellitus. Diabetes 28: 294-299

Received: July 7, 1980

Dr. A. B. Kurtz

Institute of Nuclear Medicine

Middlesex Hospital

Mortimer Street

London W1N 8AA

England 